旋回水ジェットを用いた高圧水アトマイズによる球状微粉の開発

\author{
菊川 真利, 松永 繁昌, 稲葉 恒太, 岩津 修, 武田 徹 \\ 福田金属箔粉工業森)，广607-8305 京都市山科区西野山中臣町 20.
}

\title{
Development of Spherical Fine Powders by High-pressure Water Atomization Using Swirl Water Jet
}

\author{
Masato kikukawa, Sigemasa Matsunaga, Tsuneta Inaba, Osamu Iwatsu and Tohru Takeda \\ Fukuda Metal Foil \& Powder Co., Ltd., 20 Nakatomi-cho, Nishinoyama, Yamashina-ku, Kyoto 607-8305.
}

\author{
Received November 17, 1999
}

\begin{abstract}
SYNOPSIS
In order to obtain spherical fine powders, a new high-pressure water atomization method using swirl water jet was developed. In this paper the effects of jet swirl angle $(\omega)$ upon the properties of powders were investigated. $\mathrm{Cu}-10$ mass \% Sn alloy was atomized by this method at the constant water pressure of $83.3 \mathrm{MPa}$ and constant metal orifice diameter of $4 \mathrm{~mm}$, while $\omega$ was varied from 0 to $0.18 \mathrm{rad}$.

Median diameter of the powder by the laser diffraction method $\left(D_{50}\right)$ decreased from $12.5 \mu \mathrm{m}$ to $7.5 \mu \mathrm{m}$ with increasing $\omega$, and this corresponded to Fisher average diameter $\left(\mathrm{D}_{\mathrm{FS}}\right)$ at about $\omega=0.18 \mathrm{rad}$. The apparent and tap density of the powder increased about 1 and $1.5 \mathrm{Mg} / \mathrm{m}^{3}$ respectively, and the particle shape observed by SEM became spherical with increasing $\omega$.
\end{abstract}

\section{KEY WORDS}

spherical fine powder, water atomization, swirl water jet, median diameter, tap density

\section{1 緒 言}

近年，粉末治金用に加えて射出成形，磁性材料，導電材料 用等に微粉の需要が高まっている.これに対し微粉の収率が 高い高圧水アトマイス法 ${ }^{1,2)}$ とこの応用技術-のによる対応が進 んでいるが, 粒子の球状化には不十分で改善を要する.一般 に，水アトマイズ法で得られる粉末はガスアトマイズ法と比 較して，不規則形状で見掛密度が低く球状にはなりにくい。 この原因としては，第一にアトマイス過程において分裂途中 の溶滴か急冷凝固することと，第二に分裂した微細な溶滴の 衝突，合体による造粒粒子の生成があげられる。

ところで, 水アトマイズ法で球状の粉末を得るためには, 一般に水ジェットの頂角を小さくすることが行われている. しかし，この方法では粉末の見掛密度やタップ密度が高くな り,球状化するものの粒径が大きくなる 27-9) という問題点があ る. また, 高圧水アトマイズ法では, 従来法より溶滴の分裂 か進み微細化するか，上記第二の原因より不規則な造粒粒子 も多く発生する ${ }^{10,11)}$.このことから, 微粉の球状化には上記第 二の原因を取り除くことが重要と考え，従来の水ジェット ${ }^{12)}$ とは異なり流線が衝突しない旋回水シェットという形態を採
用した.これを用いた新たな高圧水アトマイズ法により，球 状微粉を得る目的で粒子の球状化と微細化の効果を検討した.

\section{2 実験方法}

2.1 旋回水ジェットおよびアトマイズ条件

本研究で新たに考案したノスルによる旋回水ジェットの断面 摸式図をFig.1に示す.このジェットは従来のコニカル水ジェッ トと異なり，ノスルの幾何学的焦点 (以下焦点と略す)に集中 せず,焦点近傍で空洞を形成する様に収束してくびれにこの位 置を以下neck部と呼ぶ)た後, 収束側と対称に発散する. Fig.2 にこの投影図と平面図を示す. 各流線は直線であるがそれら

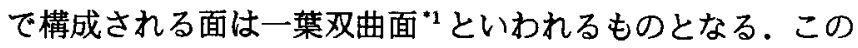
平面図における $\omega$ をジェット旋回角 (Jet swirl angle) と呼ぶ.

旋回水ジェットはノスルの環帯 (口径 20mm) から, 水圧: 83.3MPa，流量 : $2.3 \mathrm{~m}^{3} / \mathrm{ks}$ およびノスル頂角: $0.87 \mathrm{rad} の 一$ 定条 件で発生させ，ノズル内部での水の流れを制御することによ り $\omega$ のみを 0〜0.18 $\mathrm{rad}$ と変化させた.また水ジェットの状態

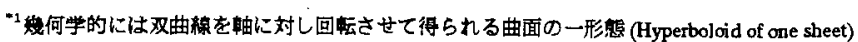


と,これによって発生する雾囲気の流れの状態を調査するた めに, $\omega=0$ と $0.18 \mathrm{rad}$ 二つの場合について, Fig.1に示した形 状の外径 $1 \mathrm{~mm}$ の圧カプローブを用い, 溶湯流の通過軸上での 圧力分布を測定した。 なお実際の旋回水ジェットを上から観 察した写真の一例を Fig.3に示す.

上記の $\omega$ を $0 \sim 0.18 \mathrm{rad}$ と変化させた旋回水ジェットの中心 軸 (以下水ジェット軸と呼ぶ) に, Cu-10mass\% Sn 合金の溶湯 を, 温度: $1473 \mathrm{~K}$, 溶湯ノスル口径: $4 \mathrm{~mm}$ で供給してアトマイ ズを行った。

2.2 粉末特性の測定

得られた粉末についてレーザー回折法による粒度分布を測

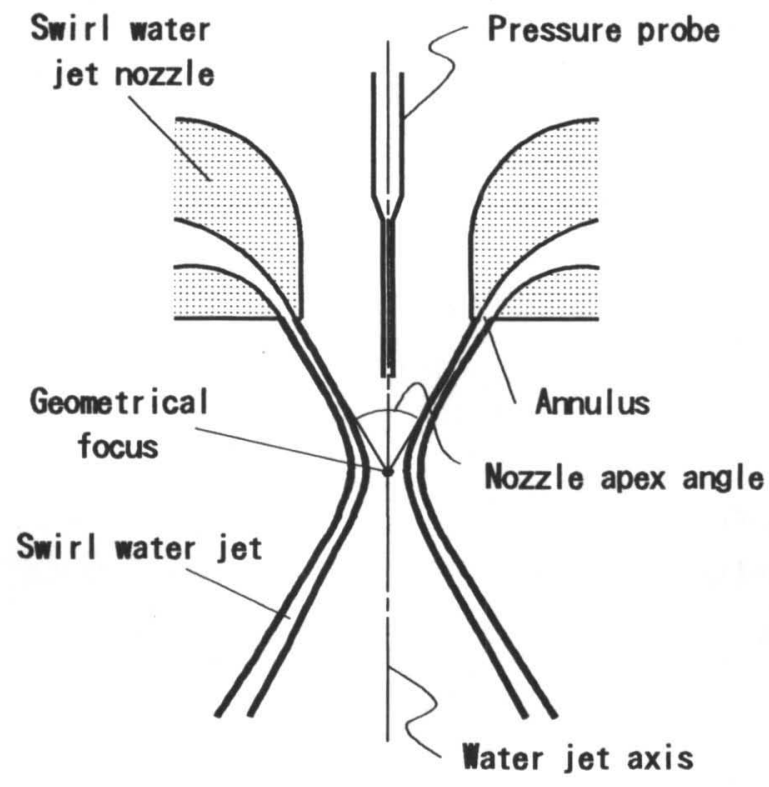

Fig.1 Schematic cross-section of swirl water jet.

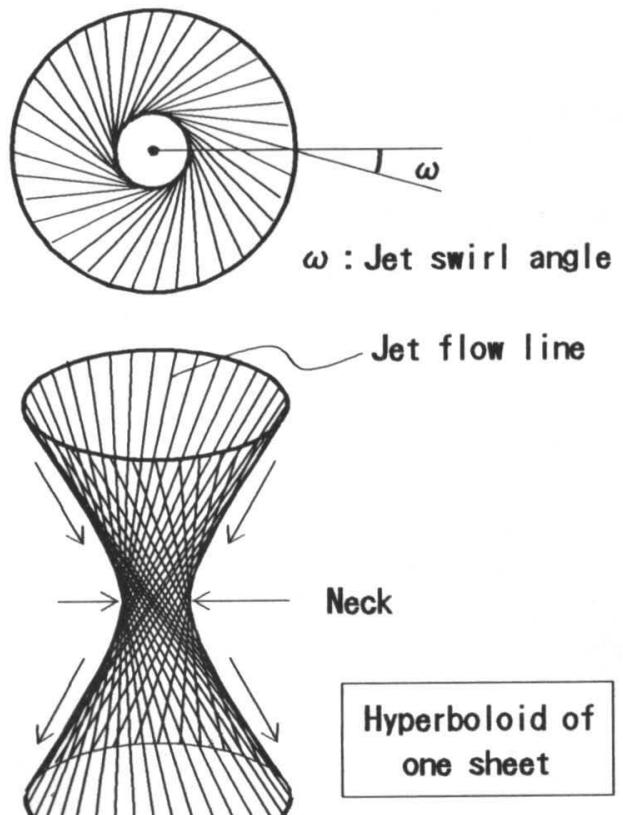

Fig.2 Schematic diagram of swirl water jet.
定し (日機装赫製； マイクロトラック粒度分析計，7997-10 $\mathrm{SRA})$, そのメジアン径を $\mathrm{D}_{50}$ とし, 幾何標準偏差を $\sigma_{\mathrm{g}}$ とした. またフィッシャー平均径を測定し(フィッシャー社製；サブ シーブサイザー, モデル 95) $\mathrm{D}_{\mathrm{FS}}$ とした.つきに見掛密度(AD) およびタッブ密度 (TD) をそれぞれ ISO 3923 および 3953 に準 拠して測定した。ささらにSEMにより粒子形状を観察した。

\section{3 実験結果およひ考察}

3.1 旋回水ジェット周辺空間の圧力変化

水ジェットが発現すると, そのエジェクター効果で水 ジェット排出側は隇圧され, 周辺の雾囲気はそれに吸引され て圧力が変わる. Fig.4に水ジェット軸上における雾囲気の圧 力分布を焦点からの距離の関数として示す. 従来のコニカル 水ジェットに相当する $\omega=0$ と, 旋回水ジェットの $\omega=0.18 \mathrm{rad}$ のいずれの場合も，圧力は $67 \mathrm{~mm}$ 位置から $40 \mathrm{~mm}$ までは徐々 に約 $-2 \mathrm{kPa}$ へと低下し，40〜20 $\mathrm{mm}$ では約 $-2 \mathrm{kPa}$ で両者とも にほぼ一定であるが, $15 \mathrm{~mm}$ 付近から $\omega=0$ と $0.18 \mathrm{rad} て ゙$ 差が現 れ始める.

この辺りまでの圧力分布は, 関らによって測定された吸引 圧力分布と類似であり,この圧力は水ジェットによって発生 した雾囲気の流れによる溶湯流の分裂を予想するための指針 となり, 分裂が開始するのは約 $-2.7 \mathrm{kPa}$ であると報告されて いる⿱ .この報告での鉄系合金に比較して本検討の $\mathrm{Cu}$ 系合金 は表面張力が低く $-2.7 \mathrm{kPa}$ より高い圧力で分裂を開始するで

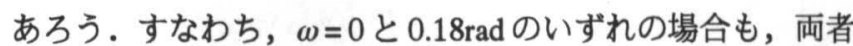
の間で圧力に差が現れ始める直前の焦点上方 $15 \mathrm{~mm}$ 付近に達 するまでに，溶湯流の分裂が開始することが予想される．本 検討でも，ほほこの $15 \mathrm{~mm}$ 付近から一次分裂を開始している ことを確認した.

つきに， $\omega=0$ の場合はさらに $5 \mathrm{~mm}$ までは約 $-4 \mathrm{kPa}$ と低下 するが，これより下方では上昇に転じ焦点でほほ $0 \mathrm{kPa}$ とな る.さらにその下方の $-2 \mathrm{~mm}$ の水ジェット内では急激に $+10 \mathrm{kPa}$ 以上の大きな正圧になっている.この様な焦点より下

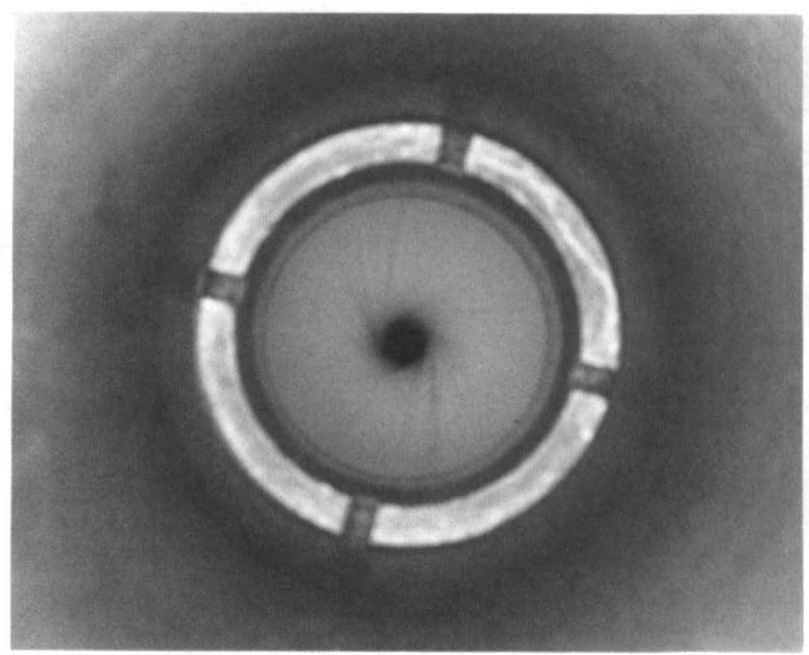

Fig.3 A photograph of high-pressure swirl water jet ( $\omega=0.14 \mathrm{rad})$. 


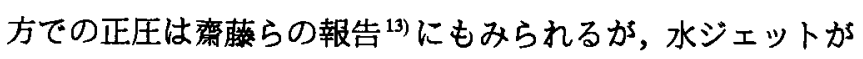
集中し衝突しているために発生すると考えられる。

一方, $\omega=0.18 \mathrm{rad}$ の場合は $15 \mathrm{~mm}$ 以下の位置では急激に低 下し，焦点近傍の 5 - $5 \mathrm{~mm}$ では-10〜-50kPaの大きな負圧 を示し， $\omega=0$ の場合とはかなり異なる圧力分布を示す.この ような旋回水ジェットでの圧力分布の測定例はないが，水 ジェット流線に囲まれた内側空間の断面積がneck部まで連続 して縮小し，それにともない雾囲気の流速が増加し圧力が低 下したと考える. neck部近傍の雾囲気の流速は, 通過する空 気の流量と断面積変化から空気中の音速の 2 倍以上と計算さ れた.また, neck 部を通過して発散側の-5〜-15mm まで圧 力はさらに-90kPaまで大きく低下し雰囲気の流速がさらに増 加していることを示す.つついて約-15mm位置から下方で圧 力は - 90 から $-75 \mathrm{kPa}$ へ急上昇し雾囲気の流速が急低下して いることを示しているが，その流速の絶対值は非常に大きい と思われる.このように旋回水ジェットは従来のコニカル水 ジェットと異なる形態と圧力分布を示し霉囲気の流速も大 きく異なる事が分かった。

\section{2 ジェット旋回角 $(\omega)$ と粉末特性}

Fig.5にD $\mathrm{D}_{50}$ におよぼす $\omega$ の影響を示す. $\omega$ を 0 から $0.18 \mathrm{rad}$ まで大きくすると得られた粉末の $\mathrm{D}_{50}$ は約 $12.5 \mu \mathrm{m}$ から約 $7.5 \mu \mathrm{m}$ へと小くなる. 水ジェットは $\omega=0$ では焦点に集中す るが, $\omega>0$ では $\omega$ をパラメータとする一葉双曲面を形成し， neck 部で水ジェット軸に同心の空洞を生じる， $\omega$ を大きくし

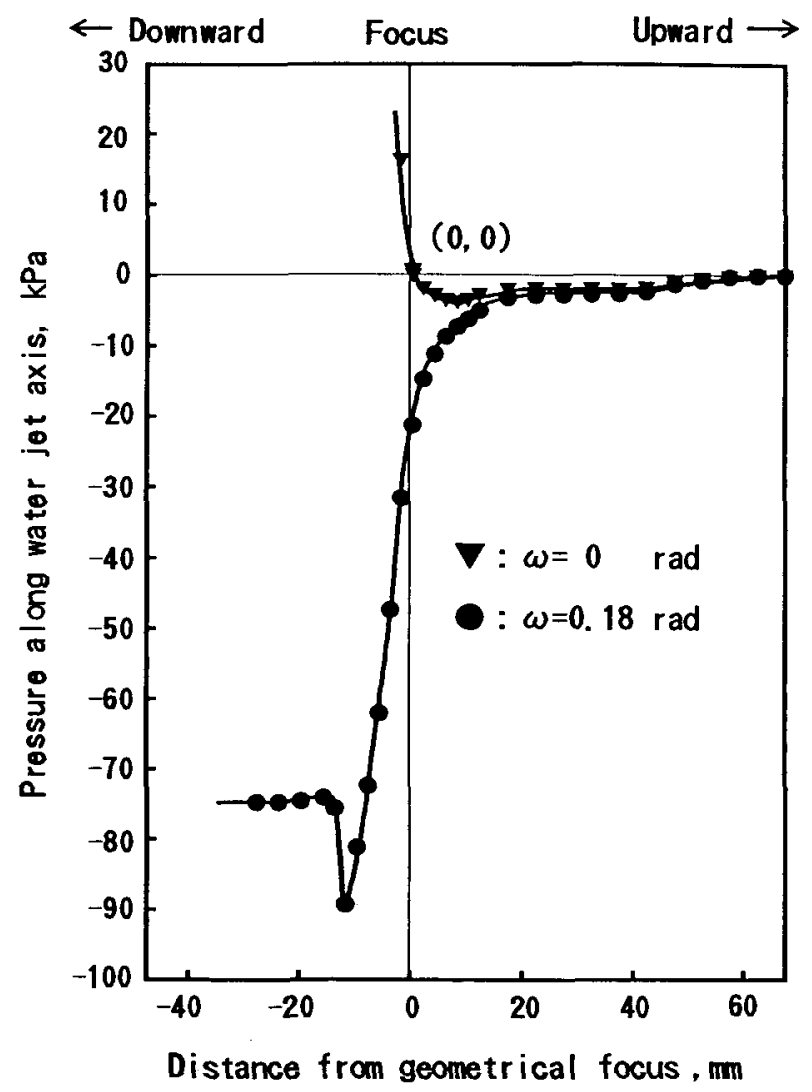

Fig.4 Pressure distributions along water jet axis.
て空洞径を增すと,ジェットの収束部断面積が増加し，そこ を通過する溶滴の分布密度が低下する.それゆえ溶滴は衝突， 合体しにくくなり，この結果造粒粒子が減少し粉末が微細化

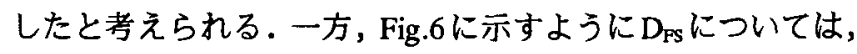
$\omega$ が変化しても $7.5 \mu \mathrm{m}$ 前後でほとんど変化しない。ここで両 者を比較してみると， $\omega$ が大きくなるにつれて $\mathrm{D}_{50}$ の值は $\mathrm{D}_{\mathrm{Fs}}$ に近づき，最終的に $\omega か ゙ 0.18 \mathrm{rad}$ 付近で両者の值はほほ一致し ている.

アトマイズ粉のように微細な溶滴の衝突，合体による造粒 粒子を含む粉末の粒度分布測定において，その測定原理 ${ }^{14)}$ か らレーザー回折法では造粒粒子を一個の粒子として測定する のに対し,フィッシャー平均径は比表面積径でその造粒粒子 を構成する一次粒子径の影響を敏感に受ける．したがって

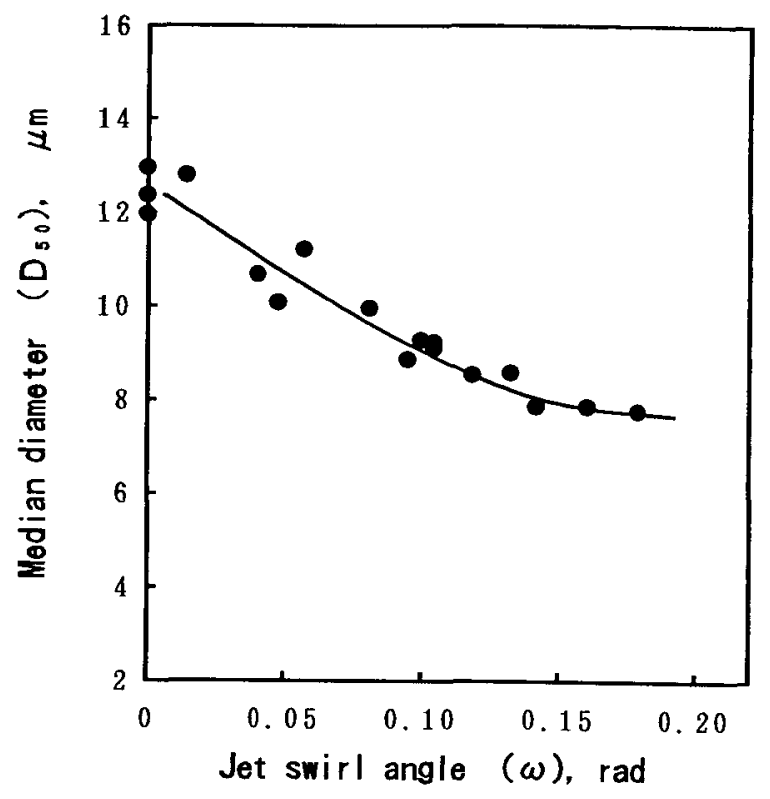

Fig.5 Change of median diameter $\left(D_{50}\right)$ as a function of jet swirl angle $(\omega)$.

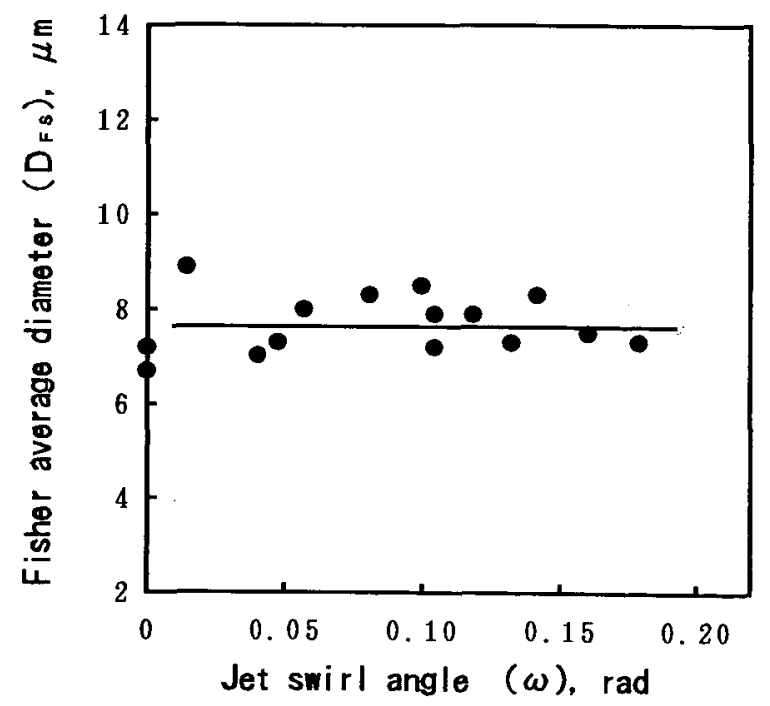

Fig.6 Change of Fisher average diameter $\left(D_{\mathrm{rs}}\right)$ as a function of jet swirl angle $(\omega)$. 
Fig.5, 6の結果は, $\omega$ が大きくなるにつれて造粒粒子の発生す る確率が低下し, レーザー回折法による $\mathrm{D}_{50}$ とフィッシャー平

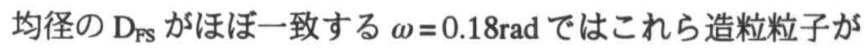
大きく減少して, 微細な一次粒子の比率が大きく上昇したこ とを裏付ける。

ところで，Fig.4で示したように $\omega=0$ に対して $\omega=0.18 \mathrm{rad}$ の場合には, 水ジェット軸での雾囲気の圧力が焦点の上方 $15 \mathrm{~mm}$ 付近以下で大きな負の值になる.このことより雾囲気 の流速は焦点の上方から急激に大きくなり，この雾囲気の流 れによる溶湯流の分裂は, $\omega=0$ より $\omega=0.18 \mathrm{rad}$ の方が促進さ れ, しかも周辺の水ジェットに対して, より均一な分散状態 で取り込まれることが期待される. $\omega>0$ の旋回水ジェットは 焦点近傍に空洞を持つが, この空洞を通過する前に, 溶滴か 水ジェットにより一次粒子の大きさにまで分裂していること がFig.5, 6の結果から推察できる.

Fig.7に $\mathrm{AD}, \mathrm{TD}$ おび各相対密度におよぼす $\omega$ の影響を示 す. $\mathrm{AD}, \mathrm{TD}$ とも $\omega$ が大きくなるにつれて高くなり, $\omega=0.18$ $\operatorname{rad}$ の各数值を $\omega=0$ と比較すると $\mathrm{AD}$ は約 $1.0 \mathrm{Mg} / \mathrm{m}^{3}$, 相対密 度で約 $10 \%$ 高く，また TD は約 $1.5 \mathrm{Mg} / \mathrm{m}^{3}$, 相対密度で約 $15 \%$

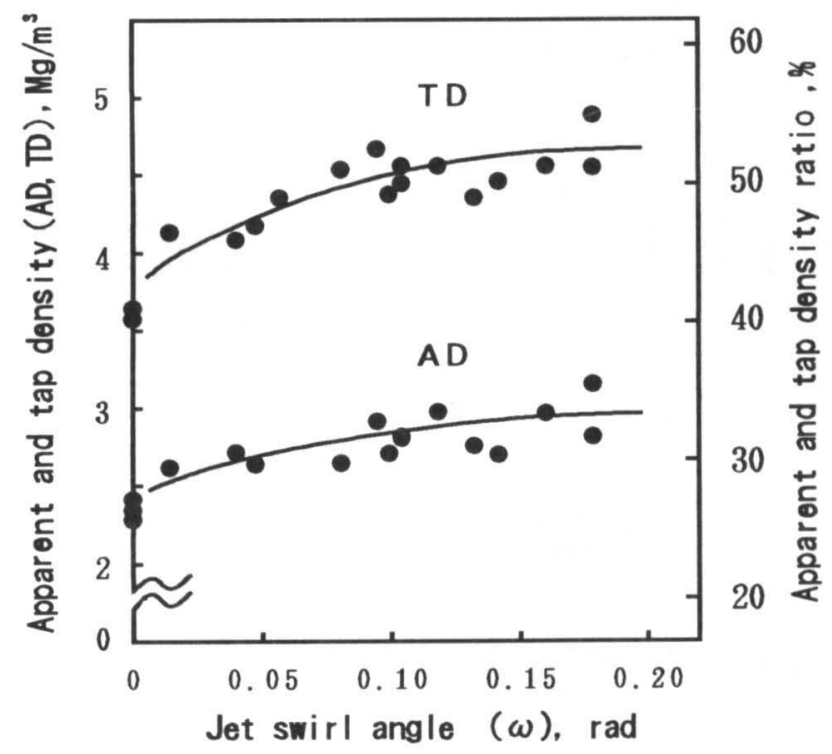

Fig.7 Change of apparent density (AD) and tap density (TD) as a functin of jet swirl angle $(\omega)$.
高くなり，これらの増加は同じ傾向を示す，一般に粒度分布 が一定の条件では, 粉末の球状化が進むほど $\mathrm{AD}, \mathrm{TD}$ が高く なるが, 上記結果は $\omega$ が大きくなるにつれて粒子が球状化し ていることを示唆している．これは，前述のように $\omega$ が大き くなるにつれて溶滴の衝突の確率が低下し, 合体, 造粒によ る不規則形状の粒子が減少することで粉末の $\mathrm{AD}, \mathrm{TD}$ が高く なったと解釈できる. また, 形状が同じでも粒子が微細化す ると粉末の $\mathrm{AD}, \mathrm{TD}$ が低くなることが知られている. しかし， $\omega$ が大きくなるにつれて Fig.5に示したように微細化するが, $\mathrm{AD}, \mathrm{TD}$ が増加傾向にあるのは造粒が抑えられることで, 球 状の一次粒子の比率が増加したためと考えられる.

Fig. 8 に $\omega=0,0.10,0.18 \mathrm{rad} て ゙$ 得られた粉末の粒子形状を示 す. (a)の $\omega=0$ では分裂した微細な溶滴が衝突, 合体したと 思われる不規則形状の造粒粒子が多く見られる. (b) の $\omega=$ $0.10 \mathrm{rad}$ では不規則形状の造粒粒子は少なく球状の一次粒子か

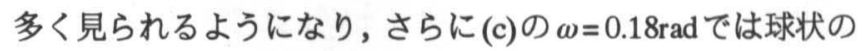
微細な一次粒子が大部分を占めるようになる.このように $\omega$ が大きなるにつれて粉末の粒子径は小さく, 形状は不規則 から球状へと変化しているが, その一次粒子径はほとんど変 化していない.これはいままで述べてきたように $\omega$ が大きく なるとともに $\mathrm{D}_{50}$ が小さくなり, $\mathrm{D}_{\mathrm{FS}}$ に近づく．また同時に $\mathrm{AD}, \mathrm{TD}$ が高くなるといった一連の結果を裹付けている.

このような粒子の造粒状態の変化から， $\omega$ が大きくなるに つれて粒度分布の広がりを表す幾何標準偏差 $\left(\sigma_{\mathrm{g}}\right)$ が小さくな ると考えられるが, Fig.9に示したように $\sigma_{\mathbf{g}}$ はほほ一定であっ た.この結果はアトマイズの圧力すなわちジェットの速度を 変化させた場合に相当する.すなわち $\omega$ が大きいほど, 微粉 化に対しジェットのエネルギーがより有効に作用することを 示唆する.

以上のことを総括して, Fig.10に(a)コニカル水ジェット $(\omega$ $=0)$ および(b) 旋回水ジェット $(\omega>0)$ の場合の粉化メカニスム の模式図を示した.

(a)の場合, 供給した溶湯は水ジェットで発生した雾囲気の 流れにより粗く分裂し水ジェットに達する.この粗い溶滴は さらに水ジェットで噴第され, より微細な溶滴となる.ここ で, $\omega=0$ で水ジェットが焦点に集中し衝突すれば, 微細な溶 滴群も焦点に集中し衝突する確率が高くなり, 合体, 造粒し
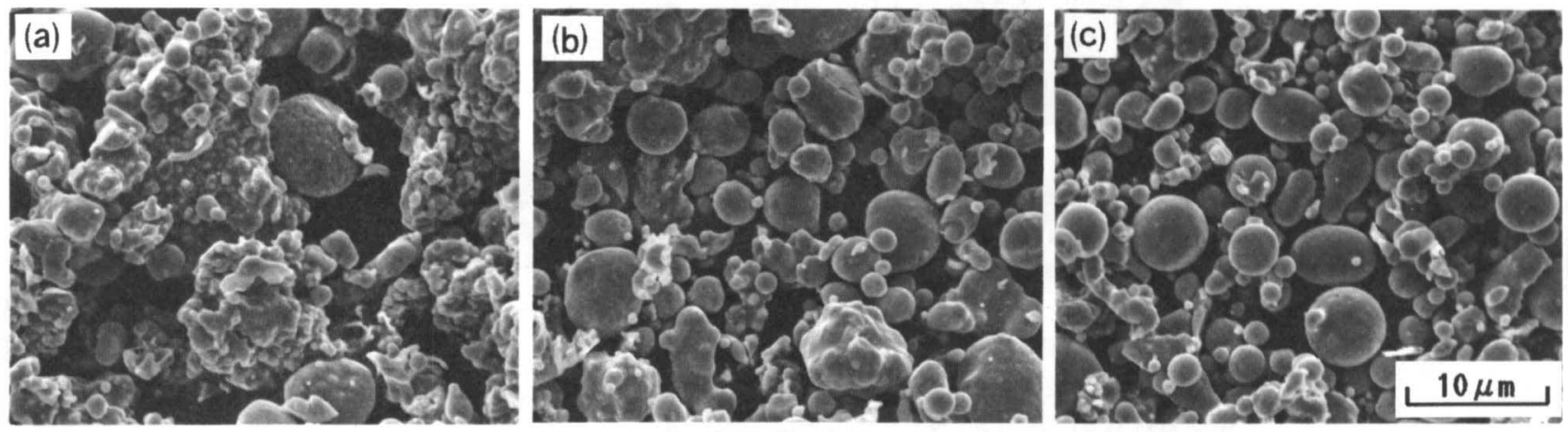

Fig.8 SEM micrographs of $\mathrm{Cu}-10 \% \mathrm{Sn}$ alloy powders produced by high-pressure water atomization using swirl water jet. (a): $\omega=0,(\mathrm{~b}): \omega=0.10,(\mathrm{c}): \omega=0.18 \mathrm{rad}$ 


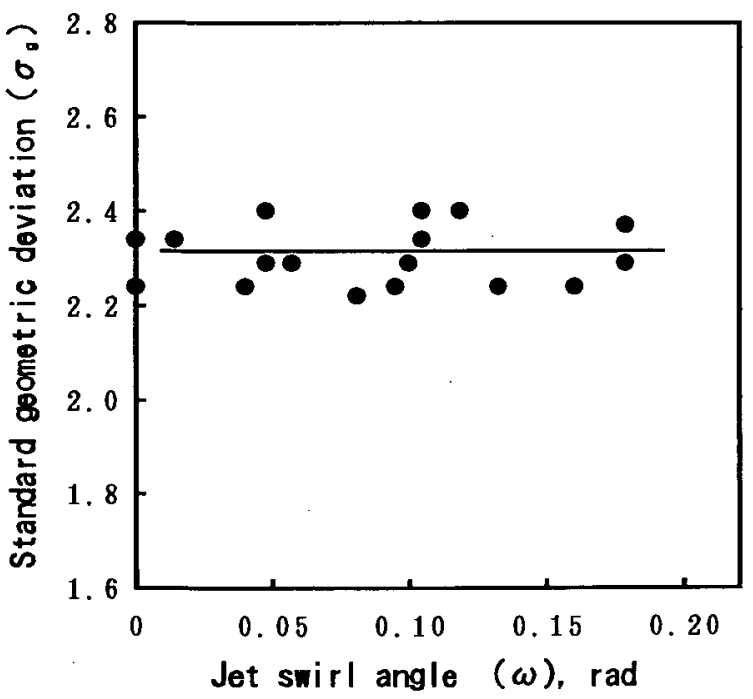

Fig.9 Change of standard geometric deviation $\left(\sigma_{\mathrm{g}}\right)$ as a function of jet swirl angle $(\omega)$.

た粗い不規則形状粒子が多く得られる.

(b)の場合も同様に雾囲気の流れにより粗く分裂した溶滴は

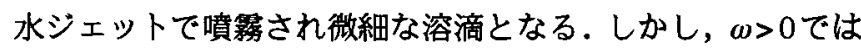
水ジェットは一葉双曲面を形成し, neck部で空洞を生じる。 $\omega$ を大きくして空洞径を增すとジェットの収束部断面積が増加 し，そこを通過する溶滴の分布密度が低下するため溶滴は衝 突，合体しにくくなり，その結果造粒粒子が減少し粉末が微 細化するとともに球状化し，最終的に球状の微細な一次粒子 に近い粉末が多く得られる.

\section{4 結 言}

球状微粉を得る目的で，従来とは異なる形態の旋回水 ジェットによる高圧水アトマイス法を試みた.Cu-10mass\%Sn 合金を用い，ジェット旋回角度 $(\omega)$ のみを変化して本法によ るアトマイズ実験を行い以下の結論を得た.

(1) $\omega$ が大きくなるに従って得られた粉末の微粉化が進み， レーザー回折法による $\mathrm{D}_{50}$ は小さくなる. その $\omega=0.18 \mathrm{rad}$ の値はフィッシャー平均径 $\mathrm{D}_{\mathrm{FS}}$ とほほ一致した。

(2) また， $\omega$ が大きくなるに従って, 粉末の見掛密度,タップ 密度が高くなり，SEMによる粒子形状観察においても粒 子の球状化および微細化が確認された。

(3) これらのことは， $\omega=0$ の場合は水ジェットが焦点で衝突 するが, $\omega>0$ では水ジェットの衝突がなく， $\omega$ が大きく なるほど分裂した微細な溶滴の衙突の確率が低くなること が主な原因と考えられる。

\section{文献}

1) 武田徹, 皆川和已: "500 $\mathrm{kgf} / \mathrm{cm}^{2}$ 水噴霧装置による金属微粉 の製造",粉体粉末冶金協会講演概要集秋季大会, (1982) 16.

2) T.Takeda: "High Pressure Water Atomization", Proc. 1993 Pow. Met. World Congress, (1993)7-12.

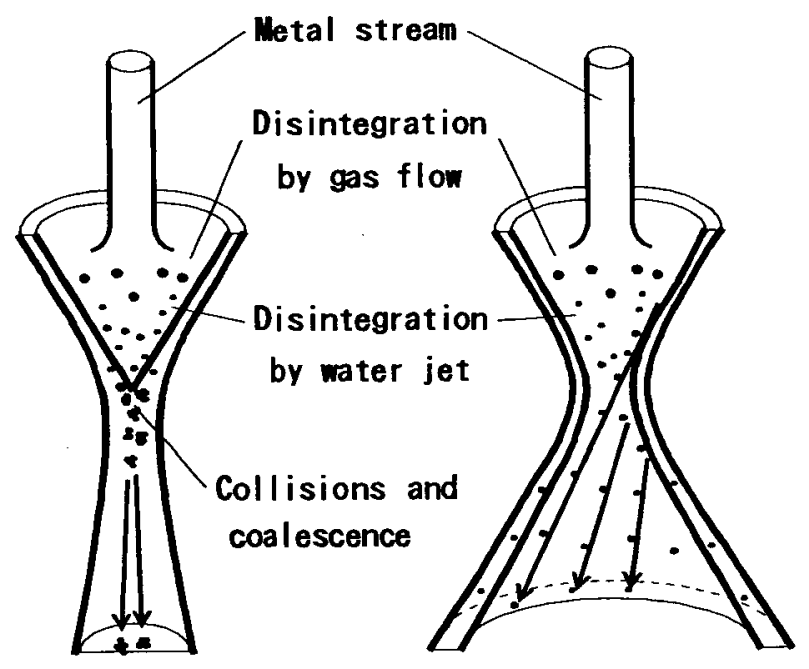

(a) Conical water jet $(\omega=0)$

(b) Swirl water jet $(\omega>0)$

Fig.10 Models for high-pressure water atomization using conical and swirl water jet.

3）岡本晋也,関義和, 滝川博, 松下富春: " 高圧水アトアイス における粉末特性に及ぼすスーパーヒートの影響",粉体 粉末治金協会講演概要集春季大会, (1990) 16.

4) 関義和, 岡本晋也, 滝川博: " 高圧水アトマイスにおける 金属粉末の微粉化挙動におよぼす水ノスルの影響", R\&D 神戸製鋼技報，40(1990)15-17.

5）日本アトマイズ加工(俶: "水アトマイズ法による射出成形 用球状粉の製造 ", 素形材, 30(1989)45.

6) 三菱製鋼儌: "超高圧水アトマイズ法による微粉末", 素形 材, 30(1989)66.

7) M.Kikukawa,T.Inaba,O.Iwatsu and H.Korekawa: "Dvelopment of Cu-Alloy Powders Superior in Compactibility by Water Atomization", Proc. 1993 Pow. Met. World Congress, (1993)70-73.

8) R.J.Grandzol and J.A.Tallmage: "Effect of Jet Angle on Water Atomization", The. Int. Nat. Jur of Powder Metallurgy \& Powder Technology, 11(1975)103-114.

9）鈴木喜代志, 近藤鉄也, 清水孝純: "球状微粉水噴霧技術 とその粉末特性", 電気製鋼, 69(1998)137-140.

10）武田徹, 皆川和己: " 球状鉄微㸮の水噴霧条件および性質 ", 粉体および粉末治金, 38(1991)102-105.

11）武田徹, 皆川和己 : "銅粉性状に及ぼす水噴霧雾囲気の影 響 ", 粉体および粉末冶金, 25(1978)213-218.

12) P.U.Gammeson: "Modern Aatomizing Techniques", Powder Metallurgy, 15(1972)67-94.

13）齋藤滋之, 園部秋夫, 駒村宏一, 香月淳一, 新田稔: " 水ア トマイス法における粉体特性におよぼす噴霧条件の影響", 粉体粉末冶金協会講演概要集春季大会, (1990)14.

14) 粉体工学会: 粒子径計測技術, 初版, 日刊工業新聞社, (1994)145-243. 